\title{
MANUFACTURING STRATEGY
}

TEXT AND CASES 
Also by Terry Hill

PRODUCTION/OPERATIONS MANAGEMENT, 2nd edn THE STRATEGY QUEST

THE ESSENCE OF OPERATIONS MANAGEMENT SMALL BUSINESS: PRODUCTION/OPERATIONS MANAGEMENT

MANUFACTURING STRATEGY, 2nd edn 


\title{
MANUFACTURING STRATEGY
}

\section{TEXT AND CASES}

\author{
Terry Hill \\ London Business School
}

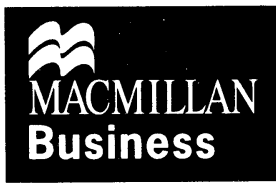


(C) Terry Hill 1995

Softcover reprint of the hardcover 1st edition 1995

All rights reserved. No reproduction, copy or transmission of this publication may be made without written permission.

No paragraph of this publication may be reproduced, copied or transmitted save with written permission or in accordance with the provisions of the Copyright, Designs and Patents Act 1988, or under the terms of any licence permitting limited copying issued by the Copyright Licensing Agency, 90 Tottenham Court Road, London W1P 9HE.

Any person who does any unauthorised act in relation to this publication may be liable to criminal prosecution and civil claims for damages.

First published 1995 by

MACMILLAN PRESS LTD

Houndmills, Basingstoke, Hampshire RG21 2XS

and London

Companies and representatives

throughout the world

ISBN 978-1-349-13726-8

ISBN 978-1-349-13724-4 (eBook)

DOI 10.1007/978-1-349-13724-4

A catalogue record for this book is available from the British Library.

$\begin{array}{rrrrrrrrrr}10 & 9 & 8 & 7 & 6 & 5 & 4 & 3 & 2 & 1 \\ 04 & 03 & 02 & 01 & 00 & 99 & 98 & 97 & 96 & 95\end{array}$


To

$\mathrm{PM}, \mathrm{AJ}$ and $\mathrm{JB}$ 


\section{Contents}

Preface $\quad$ xi

1 International Comparisons 1

Manufacturing output 2

$\begin{array}{ll}\text { Productivity: national comparisons } & 7\end{array}$

Productivity: plant-level comparisons $\quad 8$

Why has this happened? $\quad 9$

Manufacturing strategy 16

$\begin{array}{ll}\text { Conclusion } & 19\end{array}$

$\begin{array}{ll}\text { Notes and references } & 21\end{array}$

2 Developing a Manufacturing Strategy: Principles and Concepts

Functional strategies within the context of a firm $\quad 24$

Functional executives: strategy versus other roles $\quad 25$

$\begin{array}{ll}\text { Strategies versus philosophies } & 27\end{array}$

Functional dominance within corporate strategy 28

Reasons for manufacturing's reactive role in corporate strategy $\quad 29$

The content of corporate strategy $\quad 35$

$\begin{array}{ll}\text { Developing a manufacturing strategy } & 37\end{array}$

$\begin{array}{ll}\text { Order-winners and qualifiers } & 44\end{array}$

The procedure for establishing order-winners and qualifiers $\quad 49$

Understanding the criteria chosen and their relative weightings $\quad 51$

The outputs of manufacturing strategy $\quad 53$

Conclusion $\quad 55$

Notes and references $\quad 58$

$\begin{array}{ll}\text { Further reading } & 58\end{array}$

3 Order-Winners and Qualifiers $\quad 60$

$\begin{array}{ll}\text { Strategic scenarios and approaches } & 61\end{array}$

$\begin{array}{ll}\text { Strategic vacuum } & 62\end{array}$

Understanding markets $\quad 62$

Characteristics of today's markets: difference and speed of change 
Order-winners and qualifiers: basic characteristics $\quad 64$

Order-winners and qualifiers: specific dimensions $\quad 65$

$\begin{array}{ll}\text { Benchmarking } & 95\end{array}$

Determining order-winners and qualifiers $\quad 99$

$\begin{array}{lr}\text { Conclusion } & 100\end{array}$

$\begin{array}{ll}\text { Notes and references } & 102\end{array}$

$\begin{array}{ll}\text { Further reading } & 105\end{array}$

4 Developing a Manufacturing Strategy: Methodology 106

Generic strategies: today's version of the alchemist's stone $\quad 107$

The nature of strategy: directional and iterative 107

$\begin{array}{ll}\text { Checking markets } & 108\end{array}$

Relating manufacturing to agreed markets $\quad 123$

$\begin{array}{ll}\text { Conclusion } & 128\end{array}$

$\begin{array}{ll}\text { Notes and references } & 129\end{array}$

5 Process Choice 131

$\begin{array}{ll}\text { Process choice } & 132\end{array}$

Business implications of process choice $\quad 141$

Selected business implications $\quad 145$

An overview of process choice $\quad 152$

Hybrid processes $\quad 155$

Corporate manufacturing responses to similar markets $\quad 165$

Technology strategy $\quad 166$

$\begin{array}{ll}\text { Conclusion } & 168\end{array}$

$\begin{array}{ll}\text { Notes and references } & 169\end{array}$

$\begin{array}{ll}\text { Further reading } & 171\end{array}$

6 Product Profiling 172

The need to expand manufacturing strategy's language base $\quad 173$

$\begin{array}{ll}\text { Product profiling } & 173\end{array}$

$\begin{array}{ll}\text { Company-based profiles } & 176\end{array}$

$\begin{array}{ll}\text { Process-based profiles } & 183\end{array}$

Using product profiling $\quad 184$

$\begin{array}{ll}\text { Conclusion } & 186\end{array}$

7 Focused Manufacturing: Principles and Concepts 187

$\begin{array}{ll}\text { Focused manufacturing } & 188\end{array}$

Trade-offs in focused manufacturing $\quad 193$

Alternative approaches to focused manufacturing 195

$\begin{array}{ll}\text { Plant-within-a-plant configuration } & 197\end{array}$

Focus and the product life cycle 198

Progression or regression in focused manufacturing 202

$\begin{array}{ll}\text { Conclusion } & 202\end{array}$

Ways forward: halting the drift into unfocused manufacturing 205

$\begin{array}{ll}\text { Notes and references } & 206\end{array}$ 
8 Focus: Methodology 207

$\begin{array}{ll}\text { Origins of existing plants } & 207\end{array}$

Moving to focused plants $\quad 208$

Steps towards focused plants $\quad 210$

$\begin{array}{ll}\text { Focus regression versus focus progression } & 212\end{array}$

Implementing focus: examples and illustrations $\quad 213$

$\begin{array}{ll}\text { Conclusion } & 215\end{array}$

$\begin{array}{ll}\text { Notes and references } & 216\end{array}$

9 Make or Buy? 217

$\begin{array}{ll}\text { Reasons for choosing alternative strategic positions } & 217\end{array}$

Issues involved in changing make-or-buy decisions $\quad 221$

Levels of vertical integration $\quad 226$

$\begin{array}{ll}\text { The hollow corporation } & 229\end{array}$

Alternatives to widening the internal span of process 231

$\begin{array}{ll}\text { Partnership versus threat and fear } & 238\end{array}$

$\begin{array}{ll}\text { Conclusion } & 239\end{array}$

Notes and references $\quad 241$

Further reading $\quad 242$

10 Manufacturing Infrastructure Development 244

$\begin{array}{ll}\text { Manufacturing infrastructure issues } & 246\end{array}$

$\begin{array}{ll}\text { Infrastructure development } & 248\end{array}$

$\begin{array}{ll}\text { Organizational issues } & 251\end{array}$

Operational effects of structural decisions $\quad 258$

$\begin{array}{ll}\text { Strategy-based alternatives } & 260\end{array}$

Operational control 266

Conclusion $\quad 281$

Notes and references $\quad 286$

11 Accounting and Financial Perspectives and Manufacturing Strategy 288

Investment decisions $\quad 289$

$\begin{array}{ll}\text { The need for a strategic view of investments } & 291\end{array}$

Operating controls and information $\quad 304$

The simplistic nature of accounting information 305

The need for accounting system development 308

Conclusion $\quad 315$

$\begin{array}{ll}\text { Notes and references } & 319\end{array}$

\section{CASE STUDIES}

Case 1 Aztec Holdings, Inc. 325

Case 2 Control Electronics, Inc. 341 
x Contents

Case 3 Franklin, Singleton and Cotton 356

Case 4 Hoffmann Tobacco 363

Case 5 Honeywell PACE 375

Case 6 HQ Injection Moulding Company 392

Case 7 Klein Products 409

Case 8 Meta Products 420

Case 9 Millstone Packaging 440

Case 10 Nolan and Warner Plc 448

Case 11 Ontario Packaging 456

Case 12 Peterson Carton Services 460

Case 13 Precision Steel Plc 486

Case 14 Remington Products, Inc. 506

Case 15 Rumack Pharmaceuticals 525

Case 16 Santal (SA) 534

Case 17 Shire Products 543

Case 18 Tama Electronics, Inc. 565

Case 19 The Great Nuclear Fizzle at Old B \& W 577

Case 20 Tyndall Furniture Company (A) 590

Case 21 Tyndall Furniture Company (B) 600

$\begin{array}{lll}\text { Case } 22 & \text { Tyndall Furniture Company (C) } & 617\end{array}$

$\begin{array}{lr}\text { Index } & 630\end{array}$ 


\section{Preface}

Currently in many industrial companies, strategic developments are predominantly based on corporate marketing decisions at the front end of the debate with manufacturing being forced to react to these at the back end of the process. Since manufacturing managers come late into these discussions, it is difficult for them to successfully influence corporate decisions. All too often, the result is the formulation and later development of strategies which manufacturing is unable to sucessfully support. That is not to say that this happens for lack of trying; the work ethic is strong in the manufacturing culture. However, if the basic link between the manufacturing processes and infrastructure (i.e., manufacturing strategy) and the market is not strategically sound, then - by definition - the overall business will suffer.

The many reasons why this happens are addressed in this book. Significant among them is that typically the attention of manufacturing managers primarily focuses upon the day-to-day part of their task. It concerns operations detail and is output-oriented, while in strategic terms their role is seen as being reactive.

The purpose of this book is to attempt to raise manufacturing managers' sights and to provide the necessary strategic perspective for the task in hand. It is intended to help them analyze and discuss issues, and to think strategically. Currently, the area of manufacturing strategy is short of concepts, ideas, and language. This further hampers manufacturing managers in sustaining strategic argument. The book goes some way toward correcting this position. It helps provide insights and evaluates manufacturing's corporate contribution through strategic perspectives, rather than just through operational performance. It not only helps manufacturing managers to develop and provide appropriate corporate level inputs, but also enables other executives to recognize and appreciate the strategic perspectives which emanate from manufacturing and which need to be given due consideration within the corporate debate.

The strategic perspective of manufacturing forms the basis on which the book is written, but the approach places these issues within the 
rightful context of the corporate whole. Thus, it recognizes that in today's world the majority of companies will be unable to sustain success over a long period of time if their strategy is based upon a single function's view of what is important. The book, therefore, emphasizes the essential requirement to link with marketing perspectives those of manufacturing and other functions in order to determine the best strategies for the business as a whole.

In summary, the book is written as an attempt to:

1. Close the gap between manufacturing and marketing in terms of corporate strategy formulation.

2. Provide a set of principles and concepts which are pragmatic in nature and designed to be applied to each different part of a business.

3. Offer an analytical approach to the development of manufacturing strategy rather than advocate a set of prescriptive solutions. Each business and each part of each business is different. The resolution of strategy through prescription, therefore, is by definition inappropriate. Furthermore, the complexity in manufacturing is such that it encourages companies to take strategic shortcuts. As a consequence, prescriptive approaches seem attractive. The book argues strongly against such approaches. In suggesting a means of developing a manufacturing strategy and raising essential issues throughout, it provides a way of coping with this complexity. The principles and concepts outlined provide a basis for placing operational detail in an essential strategic framework.

Outlined in the book is a basic approach to developing a manufacturing strategy which has been used successfully in many companies throughout the world. It provides a logical, practical, and effective way for manufacturing to interface with marketing in formulating corporate strategy. In so doing, it ensures that the 'front-end' debate concerns not just the outward-looking stance of marketing, but the outwardlooking stance of the business as a whole. This thereby reduces the number of situations in which marketing-led strategies may be adopted which - in overall terms - will be harmful to the business. It does this by emphasizing the consequences for the total business of different decisions - a technique which is a prerequisite for developing sound strategic direction.

Many executives shy away from discussions of manufacturing because they see it as an area of minute detail. This is because, traditionally, manufacturing is presented in this form. The approach in this book is to group together relevant operational detail into key strategic issues, and to provide an understanding of how these can be applied in companies. The development of a strategic language also provides the opportunity of moving away from what often constitutes current 
practice - a discussion of operational problems. This is not only an inappropriate manufacturing contribution at the executive level, but also has the effect of dulling the interest of other functions in examining the manufacturing issues involved. Strategic language, on the other hand, helps to orient and maintain the debate at the appropriate level. It stimulates executive interest and enables others to address the complexity by creating a manageable number of manufacturing variables.

The book comprises eleven chapters. Chapter One sets the scene by drawing some important international comparisons at national, industry, and plant levels. The figures embody a growing awareness of the fact that those countries which clearly emphasize the importance of manufacturing's contribution to business success have consistently outperformed other developed countries with a sound industrial tradition.

The core of the book is in the nine central chapters. The headings highlight some key developments within manufacturing strategy. Together they form the substance of the language development as well as the methodologies to be used in its formulation. Chapters Two, Three and Four provide the context and centent on the approach to be adopted when developing a manufacturing strategy and details what needs to be undertaken at each step. It includes some illustrations to help with this explanation. Chapter Five deals exclusively with the choice of manufacturing process, the basis for that choice, and the business implications which follow. Chapter Six introduces the concept of product profiling which provides companies with a methodology for testing the current or anticipated future level of fit between the characteristics of their markets and those of their manufacturing processes and infrastructure. Chapters Seven and Eight deal with the concept of focus and the need to assign plants or parts of a plant to a defined set of tasks. The latter provides a detailed methodology statement on how to undertake this development. Chapter Nine is concerned with examining the implications behind make or buy decisions. Companies need to address this strategic option as to where they should position themselves on the process spectrum. Although at first sight these last three chapters appear to concern solely manufacturing process decisions, it is important to recognize that they are also a critical part of infrastructure formulation, since the size and shape of plants are significant factors in what constitutes an appropriate infrastructure, the subject of Chapter Ten. This chapter introduces some important concepts as a way of providing a business with the insights necessary to formulate developments in the wide range of functions within manufacturing. This approach therefore will enable these important, expensive, and time-consuming tasks to be designed in order to support the requirements of a business. It will enable them to be given strategic shape and direction rather than emanating from specialized perspectives. 
xiv Preface

The final chapter concerns the area of accounting and finance, which is important because it provides some of the essential basic data used in the formulation of strategic decisions. As with Chapter Ten, it is not intended to be a comprehensive statement of the area, but only to represent some production management views of serious shortcomings in this essential information provision. The professional accountant may find the approach provocative; it is intended, however, to be more constructive than that. The issues raised aim to challenge current practice and ideas as a way to stimulate improvement.

Finally, I trust that all who use the book will find it helpful. It is vital that manufacturing take its full part in strategic formulation if industrial companies are to prosper in the face of world competition. 